\title{
Analisis kesehatan Keuangan dengan Menggunakan Metode Altman Z- Score Pada PT Tiga Pilar Sejahtera Food Tbk
}

\author{
Apriatni Endang Prihatini ${ }^{1, *}$, Dinalestari Purbawati ${ }^{2}$ \\ ${ }^{1,2}$ Departemen Administrasi Bisnis, FISIP, Universitas Diponegoro, Semarang, Indonesia \\ *Email: apriatni_ep@yahoo.co.id
}

\begin{abstract}
Annual report information is needed for investors to determine the rate of return on paid up capital to the company and to predict the level of risk. Based on the consolidated annual report, PT Tiga Pilar Sejahtera Food Tbk (TPSF) did not show good financial performance, so it was unable to pay dividends. This study is descriptive, which is to find out the financial health of TPSF for the period of 2016 to 2019. The method of analysis used the Altman Z-Score which was equipped with a profitability ratio. The data used was secondary data obtained from official company sources, specifically the 2016 to 2019 annual report data. The results show that the company's financial condition from 2016 to 2019 was in the bankruptcy category. This condition is also strengthened by a comparative analysis of profitability ratios that shows its inability to make a profit. The increasing of company's ability to earn profits began to occur in 2019, however the financial condition was still in the bankruptcy category. It is recommended that companies prioritize strategies that can increase profits from the main business
\end{abstract}

\begin{abstract}
Abstraksi: Informasi laporan tahunan diperlukan bagi para investor, untuk mengetahui tingkat pengembalian dana yang disetorkan kepada perusahaan, serta memprediksi tingkat risiko. Berdasarkan laporan tahun konsolidasi, kondisi keuangan PT Tiga Pilar Sejahtera Food Tbk (TPSF), tidak menunjukan kinerja yang baik, sehingga tidak mampu membayar dividen. Penelitian ini bersifat diskriptif, yaitu dimaksudkan untuk mengetahui kondisi kesehatan TPSF untuk periode tahun 2016 hingga 2019. Metode analisis menggunakan Altman Z-Score dilengkapi dengan rasio profitabilitas. Penelitian ini menggunakan data sekunder yang diperoleh dari data resmi perusahaan, yaitu data laporan tahunan 2016 hingga tahun 2019. Hasil penelitian menunjukan bahwa kondisi keuangan perusahaan periode tahun 2016 sampai dengan 2019 berada pada kategori kebangkrutan. Diperkuat dengan analisis perbandingan rasio profitabilitas, menunjukkan ketidakmampuan memperoleh keuntungan. Peningkatan kemampuan memperoleh keuntungan, mulai terjadi di tahun 2019, walau demikian, kondisi keuangan, masih dalam kategori kebangkrutan Disarankan perusahaan lebih mengutamakan strategi-strategi yang dapat meningkatkan keuntungan yang berasal dari usaha pokok.
\end{abstract}

Kata kunci: Kebangkrutan; Kesehatan Keuangan; Dampak Informasi; Tingkat Risiko

\section{Pendahuluan}

PT Tiga Pilar Sejahtera Food Tbk (TPSF), beroperasi sejak 1959, dengan memiliki core bisnis di bidang bahan makanan. Pada awalnya perusahaan memproduksi bihun cap "Cangak Ular" di Sukoharjo, Jawa Tengah, selanjutnya berkembang dengan produksi beragam bahan makanan. Pada tahun 1992, dipimpin oleh Priyo Hadisutanto, diformulasikan dalam bentuk badan hukum Perseroan Terbatas. Sesuai Undang-undang no 40 tahun 2007, sebagai perusahaan dengan badan hukum Perseroan Terbatas, didirikan untuk melakukan aktivitas usaha bermodal dasar dalam bentuk saham. TPSF sebagai PT Terbuka (Tbk) memiliki kewajiban memenuhi kewajiban pembayaran dividen kepada pemegang saham. Dalam hal terjadi kerugian dari operasi usaha, maka pemegang saham tidak akan mendapatkan bagian keuntungan atau dividen.

Pada tahun 2016 hingga tahun 2019, dilihat dari laporan keuangan, perusahaan mengalami perubahan keuntungan/kerugian yang signifikan. Data perubahan keuntungan/kerugian TPSF ditunjukkan pada Tabel 1.

Dimulai dari tahun 2017, prosentase perubahan laba/rugi, mengalami kerugian sebesar 827,76\%. Tahun 2018, masih mengalami kerugian, walaupun tingkat kerugian lebih rendah dibanding tahun 2017. Tahun 2019, operasi perusahaan mengalami perkembangan, hingga menghasilkan keuntungan. 
Tabel 1. Laba/rugi PT TPSF Tahun 2016-2019 (000)

\begin{tabular}{crrr}
\hline Tahun & Laba/Rugi Bersih (Rp) & Perubahan (Rp) & \% Perubahan Laba/rugi \\
\hline 2016 & 719.228 .000 & - & - \\
\hline 2017 & $(5.234 .288 .000)$ & $(5.953 .516 .000$ & $(827,76)$ \\
\hline 2018 & $(123.510 .000)$ & 5.110 .778 .000 & $(97,64)$ \\
\hline 2019 & 1.134 .780 .000 & 1.258 .290 .000 & $(1.018,77)$
\end{tabular}

Sumber: Laporan keuangan PT Tiga Pilar Sejahtera Food, Tbk, tahun 2016-2019

Kondisi keuangan dipengaruhi oleh permasalahan internal perusahaan, dikutip dari laporan keuangan tahun 2018, yaitu penolakan oleh pemegang saham atas Laporan Tahunan periode 2017 serta diberhentikannya direksi dalam Rapat Umum Pemegang Saham (RUPS) pada 27 Juli 2018. Sejak tanggal 5 Juli 2018, perusahaan mengalami gagal bayar atas bunga obligasi serta Sukuk Ijarah TPS Food 1 tahun 2013. Atas kegagalan tersebut, perusahaan mengajukan Permohonan Penundaan Kewajiban Pembayaran Utang (PKPU). Selanjutnya atas permasalahan tersebut, pada tanggal 23 Mei 2019, Berdasarkan putusan hukum telah memutuskan secara sah rencana perdamaian antara PT Tiga Pilar Sejahtera Food Tbk. dengan para kreditornya yang di dalamnya berisi kesepakatan mengenai restrukturisasi pembayaran utang.

Berdasarkan informasi laporan keuangan, dapat diketahui bahwa perusahaan mengalami kesulitan keuangan (Financial Distress). Menurut Kamaludin (2015), Financial Distress kondisi yang menandai perusahaan sedang bermasalah dalam keuangan, yaitu dicirikan dengan perusahaan mengalami kondisi rugi. Financial distress harus segera ditangani untuk mencegah kebangkrutan. Kondisi financial distress dialami oleh TPSF, dengan melihat capaian keuntungan yang rendah, serta kerugian yang sangat besar terjadi pada tahun 2017. Operasional di tahun 2018 dan 2019, belum menunjukkan kinerja keuangan yang membaik. Struktur modal perusahaan, menjadi permasalahan yang berat, karena sejak tahun 2017 hingga tahun 2019, perusahaan mengalami total ekuitas negatif. Hal ini terjadi dikarenakan pada tahun 2017 dan 2018 emiten AISA (PT TPSF) disuspensi oleh Bursa Efek Indonesia (BEI) karena hasil audit oleh Akuntan Publik (KAP) atas laporan keuangan menghasilkan opini DISCLAIMER, dan laporan keuangan juga ditolak pada RUPS. Hal ini menunjukkan bahwa laporan keuangan tidak memenuhi standar PABU dan SAK.

Penelitian terdahulu oleh Dahni (2019) yang melaksanakan penelitian untuk menganalisis kondisi keuangan PT TPSF pada tahun 2015-2017, menggunakan pendekan Model Altman Z-Score menunjukkan bahwa PT TPSF terindikasi kebangkrutan (Distress zone). Melalui penelitian ini, dimaksudkan untuk mengetahui kondisi keuangan perusahaan tahun 2016 hingga tahun 2019, menggunakan pendekatan Altman Z-Score. Dengan menyediakan informasi yang berkelanjutan bagi investor maupun calon investor, dapat digunakan untuk memprediksi kemampuan perusahaan memenuhi kewajiban keuangan bagi investor dan calon investor, serta memperhitungkan tingkat pengembalian modal.

\section{Kajian Teori}

\section{Konsep Financial Distress}

Brigham dan Daves (2003) menyatakan bahwa, financial distress diawali saat

Tabel 2. Data Keuangan PT TPSF tahun 2016-2019 (000)

\begin{tabular}{lllll}
\hline \multicolumn{1}{c}{ Uraian } & $\mathbf{2 0 1 9}$ & $\mathbf{2 0 1 8}$ & $\mathbf{2 0 1 7}$ & $\mathbf{2 0 1 6}$ \\
\hline Total Hutang & 3.526 .820 .000 & 5.267 .350 .000 & 5.329 .841 .000 & 4.990 .139 .000 \\
\hline Total ekuitas & $(1.657 .850 .000)$ & $(3.450 .940 .000)$ & $(3.347 .901 .000)$ & 4.264 .400 .000 \\
\hline Total Aset & 1.868 .970 .000 & 1.1 .816 .410 .000 & 1.981 .940 .000 & 9.254 .539 .000 \\
\hline Sumber: Data laporan keuangan PT Tiga Pilar Sejahtera Food, Tbk, tahun & $2016-2019$
\end{tabular}


perusahaan tidak dapat memenuhi jadwal pembayaran atau saat proyeksi arus kas, hal ini menunjukkan bahwa perusahaan tersebut terindikasi tidak dapat memenuhi kewajibannya. Financial distress, ditunjukkan dengan tingkat likuiditas yang rendah, yaitu kondisi hutang jangka pendek tidak lebih besar dari total aktiva lancar, serta insolvable, yaitu kondisi tidak mampu membayar hutang jangka panjang. Selanjutnya Dikutip dari Hanafi (2014) "Financial distress dapat digambarkan dari dua titik ekstrem yaitu dari pada likuiditas jangka pendek sampai insolvable (utang lebih besar dari pada aset),kesulitan keuangan jangka pendek biasanya bersifat sementara, tetapi bisa berkembang menjadi lebih buruk". Financial distress menjadi indikasi terjadinya kebangkrutan karena keadaan keuangan yang tidak sehat. Menurut Prihadi (2013), kebangkrutan (bankcruptcy) adalah kondisi yang menggambarkan perusahaan tidak dapat melunasi kewajibannya. Indikasi kebangkrutan dapat diprediksi lebih awal, dengan melakukan analisis rasio keuangan. Martin, A dalam Fakhrurozie (2007), kebangkrutan dapat meliputi beberapa kategori. Pertama, kegagalan ekonomi ialah kondisi perusahaan tidak dapat menghasilkan arus kas sesuai yang diharapkan. Kedua, financial distressed, ialah kondisi perusahaan mengalami kesulitas dana, baik dalam hal modal kerja maupun kas.

Rodoni dan Ali (2010) menyatakan bahwa financial distress ditandai kondisi keuangan yang tidak memenuhi standar. Pertama, ketidakcukupan modal. Kedua, besarnya beban hutang dan bunga. Ketiga, mengalami kerugian dalam operasi perusahaan. Ketiga kondisi keuangan tersebut, jika tidak diatasi dengan tepat, akan berakibat pada kebangkrutan. Perlu adanya tindakan strategis untuk mengatasi, sehingga dapat menciptakan keseimbangan antara modal dan hutang. Seperti diungkapkan oleh Platt dan Platt, dalam Almilia dan Kristijadi (2003), bahwa kondisi financial distress adalah tahapan turunnya kondisi keuangan sebelum terjadinya kebangkrutan.

Faktor penyebab terjadinya financial distress dinyatakan oleh Damodaran (1997), dapat disebabkan faktor internal perusahaan. Pertama, kesalahan dalam memperhitungkan jumlah hutang, sehingga perusahaan tidak dapat menutup kewajiban hutang, pada saat hutang telah jatuh tempo. Kedua, mengalami kerugian yang disebakan karena penghasilan dari operasi perusahaan tidak dapat menutup beban usaha. Ketiga, pengelolaan arus kas tidak tepat, dapat menyebabkan arus penerimaan dan pengeluaran tidak sebanding. Ketidaktepatan dalam pengelolaan keuangan ditunjukkan dari perhitungan rasio-rasio keuangan. Kondisi kesulitan keuangan yang dialami perusahaan dalam kurun waktu tertentu, menjadi indikasi terjadinya kebangkrutan (Rahayu \& Putri, 2016).

Prediksi kondisi kesehatan keuangan perusahaan bermanfaat untuk pihak-pihak intern maupun ekstern dalam perusahaan. Rudianto (2013) menemukan bahwa pihakpihak yang berkepentingan terhadap prediksi kebangkrutan, yaitu: Pertama, investor dapat memutuskan membeli atau tidak atas saham dari peusahaan yang terindikasi kebangkrutan. Kedua, pemberi pinjaman (debitur) akan memonitor perkembangan usaha perusahaan untuk selanjutnya apakah akan diberikan pinjaman atau tidak. Ketiga, manajeman perusahaan perlu melakukan tindakan penyelamatan. Keempat, pemerintah bertanggung jawab terhadap kondisi keuangan, untuk mempertimbangkan kondisi para karyawan. Kelima, Akuntan Publik berkepentingan untuk mengetahui kemampuan going concern perusahaan yang sedang di audit.

\section{Rasio Keuangan}

Informasi mengenai kondisi kesehatan suatu perusahaan go public, dapat diamati melalui laporan keuangan. Setiap perusahaan memiliki tanggung jawab penyusunan serta penyajian data laporan keuangan yang telah sesuai Standar Akuntansi Keuangan. Termasuk dalam hal ini penyusunan laporan keuangan, sebagai bentuk pertanggungjawaban terhadap para pemegang saham dan pihak-pihak yang berkepentingan terhadap operasi perusahaan. Bagi investor informasi laporan keuangan menjadi dasar dalam pengambilan keputusan untuk menanamkan modal pada perusahaan. Penilaian atas kinerja keuangan dapat menunjukan kemampuan perusahaan dalam pengelolaan keuangan. Gitman (2006), menyatakan bahwa kegagalan 
usaha dapat diprediksi dengan menganalisis rasio keuangan perusahaan. Pertama, rasio likuiditas, menunjkkan kemampuan membayar hutang jangka pendek. Kedua, rasio profitabilitas, menunjukkan kemampuan operasional usaha, untuk menghasilkan keuntungan/kerugian. Ketiga, rasio solvabilitas menunjukkan kemampuan membayar hutang jangka Panjang. Keempat, perbandingan hutang dan modal. Semakin besar komposisi hutang dalam komposisi modal, menunjukkan semakin sulit kondisi keuangan. Pada dasarnya setiap perhitungan rasio keuangan, dapat digunakan untuk menganalisis kemampuan perusahaan atau kegagalan usaha. Kemampuan oeprasional secara efisien dan efektif dapat ditunjukan melalui perhitungan rasio yang relevan. Oleh karena itu diperlukan penetapan dan perhitungan rasio-rasio keuangan yang tepat dan benar untuk memprediksi kondisi masa depan perusahaan.

Penelitian terdahulu oleh Almilia dan Kristijadi (2003), dengan judul analisis rasio untuk memprediksi kondisi financial distress melalui analisis rasio keuangan, pada perusahaan yang terdaftar di bursa efek jakarta. Hasil penelitian menunjukan variablevariabel yang dapat menunjukan kondisi financial distress, yaitu financial leverage, profit margin, rasio pertumbuhan serta rasio likuiditas.

\section{Rasio Profitabilitas}

Menurut Hanafi (2016), Rasio profitabilitas digunakan untuk mengetahui kemampuan perusahaan dalam menghasilkan keuntungan dalam aspek penjualan, asset, serta modal saham. Indikator yang digunakan, adalah ROA, profit margin, dan ROE. Data keuangan yang digunakan untuk menghitung rasio profitabilitas, berasal dari laporan neraca dan laporan laba/rugi. Perhitungan profit margin dapat digunakan untuk mengetahui kemampuan perusahaan memperoleh keuntungan bersih pada tingkat penjualan tertentu. Tingkat rasio tinggi akan menunjukkan kemampuan efisiensi usaha. Profit margin dihitung dengan formula sebagai berikut:

Profit margin $=\frac{\text { laba }}{\text { penjualan }}$
Return On Asset (ROA), merupakan perbandingan antara keuntungan bersih dengan tingkat asset. Menurut Kasmir (2016), rasio ini menunjukkan imbal hasil atas penggunaan seluruh aktiva. Semakin tinggi ROA, menunjukkan kemampuan perusahaan mengelola aktiva, secara baik. ROA dihitung dengan formula sebagai berikut:

$\mathrm{ROA}=\frac{\text { laba bersih }}{\text { total aset }}$

Return On Equity, digunakan untuk mengetahui kemampuan menghasilkan keuntungan didasarkan pada modal sendiri. Menurut Hanafi (2016), rasio ini terutama digunakan untuk kepentingan para investor. Rasio yang tinggi mengindikasikan profitabilitas yang tinggi. ROE dihitung dengan formula sebagai berikut:

$\mathrm{ROE}=\frac{\text { laba bersih }}{\text { modal sendiri }}$

\section{Model Altman Z-score}

Model Z-score, dikembangkan oleh Edward I. Altman pada tahun1968. Metode ini digunakan untuk memprediksi kondisi keuangan perusahaan. Potensi kebangkrutan, jika dapat dideteksi sedini mungkin akan memudahkan perusahaan untuk melakukan tindakan koreksi, sehingga lebih cepat untuk memulihkan keadaan kesulitan keuangan. Altman melakukan penelitian pada 66 perusahaan manufaktur, dengan menetapkan 5 rasio keuangan untuk menggambarkan kondisi kesehatan keuangan perusahaan. 5 rasio yang ditetapkan adalah rasio laba ditahan dengan total aktiva; rasio modal kerja dengan total aktiva; rasio nilai pasar saham dengan total hutang; rasio laba sebelum pajak dan bunga dengan total aktiva dan rasio penjualan dengan total aktiva. Berdasarkan hasil perhitungan rasio akan ditetapkan kategori 
kondisi perusahaan. Kategori yang diaplikasikan dalam model ini, adalah:

Tabel 3. Interpretasi Model Altman ZScore Z (0)

\begin{tabular}{cc}
\hline Skor $\mathbf{Z}$ & Indikasi \\
\hline$<1,81$ & Bangkrut \\
\hline $1,81-2,99$ & $\begin{array}{c}\text { Grey area / Zone of } \\
\text { ignorance }\end{array}$ \\
\hline$>2.99$ & Tidak Bangkrut \\
\hline
\end{tabular}

Rasio-rasio ditetapkan sebagai berikut:

X1: Modal kerja dibagi total aktiva

X2: Laba ditahan dibagi total aktiva

X3: Laba sebelum pajak dan bunga dibagi total aktiva

X4: Nilai pasar saham dibagi dengan total hutang

X5: Penjualan dibagi total aktiva

Berdasarkan perhitungan ke lima rasio tersebut, selanjutnya dihitung dengan persamaan matematis, sebagai berikut:

$Z=1,2 X 1+1,4 X 2+3,3 X 3+0,6 X 4+1,0 X 5$

Model Altman mengembangkan prediksi kebangkrutan dengan menggunakan analisis perhitungan rasio keuangan (Arum \& Handayani, 2018). Dalam penelitian ini akan menggunakan rasio profitabilitas. Van Horne dan Wachowicz (2005) mengemukakan, bahwa rasio profitabilitas merupakan rasio yang dapat menjelaskan kemampuan keuangan dikaitkan dengan penjualan dan investasi.

\section{Metode}

Penelitian ini adalah penelitian deskriptif, yaitu memberikan gambaran atas kondisi keuangan PT Tiga Pilar Sejahtera
Food Tbk, untuk tahun 2016 hingga tahun 2019. Analisis prediksi kondisi keuangan menggunakan: Pertama, Model Altman ZScore. Model ini digunakan untuk prediksi apakah perusahaan dalam keadaan keuangan yang sehat, atau atau indikasi kebangkrutan. Model ini menggunakan komponen rasio keuangan yang telah ditetapkan. Hasil perhitungan rasio, dimasukan dalam persamaan matematis rumus Z- Score, dan hasilnya akan dapat ditetapkan, kategori keadaan kesehatan keuangan perusahaan. Langkah pertama yang dilakukan adalah menetapkan tingkat rasio, yaitu: rasio laba ditahan dengan total aktiva; rasio modal kerja dengan total aktiva; rasio nilai pasar saham dengan total hutang, rasio laba sebelum pajak dan bunga dengan total aktiva dan rasio penjualan dibagi total aktiva. Selanjutnya menghitung nilai $Z$, yaitu dengan mengalikan tingkat rasio dengan skor yang telah ditetapkan. Membandingkan skore $\mathrm{Z}$ dengan standar yang ditetapkan, dapat menentukan kategori kesehatan keuangan perusahaan. Kedua, rasio profitabilitas, yaitu return on aset, net profit margin, return on equity. Jenis data yang digunakan adalah data sekunder, yaitu laporan tahunan perusahaan TPS Food tahun 2016 hingga tahun 2019, yang dipublikasikan melalui https://tpsfood.id/relasi-investor/laporantahunan/

\section{Hasil dan Pembahasan}

Berdasarkan model Altman Z-Score, ditentukan rasio keuangan, untuk tahun 2016 hingga tahun 2019 ditunjukkan pada Tabel 4.

Berdasarkan perhitungan dengan rumus Altman Z-Score, diketahui bahwa hanya kondisi tahun 2016 berada pada indikasi Grey

Tabel 4. Perhitungan Metode Z-Score

\begin{tabular}{|c|c|c|c|c|c|c|c|c|c|}
\hline \multicolumn{2}{|r|}{ Rasio } & \multicolumn{2}{|c|}{2016} & \multicolumn{2}{|c|}{2017} & \multicolumn{2}{|c|}{2018} & \multicolumn{2}{|c|}{2019} \\
\hline $\mathrm{X} 1$ & Modal kerja/total aktiva & 0,372 & 0,446 & $-1,651$ & $-1,981$ & $-2,416$ & $-2,899$ & $-0,363$ & $-0,436$ \\
\hline $\mathrm{X} 2$ & Laba di tahan/total aktiva & 0,426 & 0,596 & $-1,688$ & $-2,363$ & $-1,899$ & $-2,279$ & $-1,000$ & $-1,400$ \\
\hline X3 & $\begin{array}{l}\text { Lba sebelum pajak dan } \\
\text { bunga/total aktiva }\end{array}$ & 0,138 & 0,455 & $-2,573$ & $-8,490$ & $-0,005$ & $-0,017$ & 0,796 & 2,627 \\
\hline $\mathrm{X} 4$ & $\begin{array}{l}\text { Nilai pasar saham / dengan } \\
\text { total hutang }\end{array}$ & 0,001 & 0,00078 & 0,000 & 0,000 & 0,000 & 0,000 & 0,000 & 0,000 \\
\hline $\mathrm{X} 5$ & Penjualan dibagi total aktiva & 0,707 & 0,707 & 0,984 & 0,984 & 0,872 & 0,872 & 0,808 & 0,808 \\
\hline & Altman Z-Score & & 2,205 & & $-11,85$ & & $-4,323$ & & 1,599 \\
\hline
\end{tabular}


area yaitu kondisi tidak pasti, bisa berpotensi mengalami kebangkrutan, sedangkan tahun 2017 dan 2018, berada pada indikasi bangkrut. Tahun 2019 kondisi perusahaan lebih baik dibandingkan 2 tahun sebelumnya, akan tetapi tetap dengan model Altman Z Score, masih berada pada indikasi bangkrut.

Tabel 5. Indikasi kondisi Keuangan PT TPSF

\begin{tabular}{ccc}
\hline & $\begin{array}{c}\text { Altman Z- } \\
\text { Score }\end{array}$ & Indikasi \\
\hline 2016 & 2,205 & $\begin{array}{c}\text { Grey area/ Zone } \\
\text { of ignorance }\end{array}$ \\
\hline 2017 & $-11,850$ & Bangkrut \\
\hline 2018 & $-4,323$ & Bangkrut \\
\hline 2019 & 1,599 & Bangkrut \\
\hline
\end{tabular}

Hasil analisis rasio keuangan, dapat diketahui bahwa telah terjadi permasalahanpermasalahan keuangan. Pertama, modal kerja dibagi total aktiva, yang mana modal kerja adalah rasio yang dapat menunjukkan kemampuan perusahaan mengelola total aktiva sehingga dapat menghasilkan modal kerja. Brigham dan Houston (2011) menemukan bahwa modal kerja ialah investasi perusahaan atas aset-aset jangka pendeknya. Total aktiva tahun 2017 hingga 2019, terus mengalami penurunan yang signifikan dibanding tahun 2016, sedangkan jumlah modal kerja, mulai tahun 2017 hingga 2019, negatif. Modal kerja dengan angka negatif, sangat membahayakan perusahaan. Kondisi keuangan yang baik, menurut Sawir (2005) adalah jika perusahaan memiliki modal kerja yang permanen, yaitu modal kerja dalam jumlah yang ditentukan, harus tersedia, untuk membiayai operasional perusahaan, sehingga kelancaran usaha terjamin Kondisi keuangan dilihat dari rasio ini, akan berpengaruh terhadap kemampuan operasi perusahaan, dan juga akan berdampak pada kesulitan membayar kewajiban kepada investor.

Persentase aktiva lancar terhadap total aktiva, dari tahun 2017 hingga 2019, terus mengalami penurunan dan prosentase hutang lancar terhadap total hutang, pada tahun 2017 hingga tahun 2018, mengalami peningkatan signifikan, selanjutnya mengalami pengurangan di tahun 2019. Kedua, Laba di tahan dibagi aktiva, Sundjaja dan Barliaan (2004) mengatakan, laba ditahan merupakan pendapatan yang tidak dibagikan sebagai dividen. Jumlah laba ditahan yang dimiliki oleh perusahaan, dapat menunjukan keadaan dimana perusahaan tidak membagikan seluruh pendapatan untuk membayar dividen kepada pemegang saham, selanjutnya jumlah laba ditahan dapat digunakan untuk mendukung operasional usaha. Jika perusahaan mengalami keadaan kerugian, tentu tidak dapat membayar dividen kepada pemegang saham. Perhitungan rasio pada TPSF, dimulai tahun 2017 hingga tahun 2019, menunjukkan angka negatif, dikarenakan tahun 2017 dan tahun 2018 perusahaan mengalami kerugian. Tahun 2019, diperoleh keuntungan tetapi tidak diimbangi dengan peningkatan total aktiva. Tahun 2017 hingga tahun 2019, perusahaan tidak menerbitkan saham baru.

Selanjutnya, perhitungan EBIT diperlukan, untuk mengetahui kemampuan operasional perusahaan dalam menghasilkan laba sebelum pajak dan bunga. Investor melihat EBIT sebagai kemampuan menghasilkan keuntungan, tanpa harus memperhitungkan biaya bunga dan pajak. Tingkat EBIT yang baik, mencerminkan keberhasilan aktivitas penjualan, sehingga tidak ada keraguan atas konsekuensi pembayaran pajak dan biaya modal atau bunga pinjaman. Diketahui bahwa tahun 2017 dan 2018, mengalami jumlah EBIT negatif. Hal ini disebabkan karena terjadi penurunan penjualan yang signifikan dibanding tahun 2016, serta berpengaruh terhadap jumlah EBIT yang negatif. Keempat, Nilai pasar saham dibagi total hutang. Nilai pasar saham diketahui berdasarkan jumlah saham yang beredar dikalikan dengan harga penutupan. Nilai pasar saham tertinggi terjadi pada tahun 2016, sedangkan sejak 2017 hingga 2019 terjadi penurunan nilai pasar saham. Rasio menunjukkan bahwa modal pinjaman lebih besar dari pada modal saham. Dalam hal ini ada indikasi perusahaan akan mengalami kesulitan dalam membayar kewajiban hutang. 
Faktor selanjutnya adalah penjualan dibagi total aktiva. Aktivitas penjualan merupakan kunci keberhasilan perusahaan untuk dapat bertahan dan berkelanjutan. Dari hasil perhitungan rasio, tidak nampak perubahan yang signifikan dari tahun 2016 hingga 2019. Akan tetapi jika dilihat dari angka nominal, dari tahun 2017 hingga 2019, terjadi penurunan penjualan, sebanding dengan terjadinya penurunan total aktiva. Hal ini mengindikasikan perusahaan tidak dapat mengoptimalkan total aktiva yang dimiliki untuk mencapai tingkat penjualan tertentu.

Indikasi terjadi kebangkrutan dengan menggunakan perhitungan model Z-Score, dimaksudkan untuk menjadikan perhatian, agar perusahaan dapat segera menetapkan strategi-strategi yang tepat untuk meningkatkan kesehatan keuangan perusahaan. Kategori untuk tahun 2019, walau berada pada kategori bangkrut namun perusahaan cenderung mengalami peningkatan operasi usaha, hal ini terlihat pada tingkat rasio yang cenderung terjadi peningkatan, terutama pada rasio laba sebelum pajak dengan total aktiva.

\section{Profitabilitas}

Untuk melengkapi pembahasan tentang kategori kinerja keuangan perusahaan, akan diuraikan perbandingan rasio profitabilitas untuk tahun 2016 hingga tahun 2019. Profitabilitas menunjukkan kemampuan perusahaan untuk mendapatkan keuntungan, dihubungkan dengan aktifitas penjualan. Berikut adalah tabel profitabilitas.

\section{Tabel 6. Profitabilitas PT TPSF}

\begin{tabular}{ccccc}
\hline Rasio & $\mathbf{2 0 1 6}$ & $\mathbf{2 0 1 7}$ & $\mathbf{2 0 1 8}$ & $\mathbf{2 0 1 9}$ \\
\hline $\begin{array}{c}\text { Net } \\
\text { Profit }\end{array}$ & $9.07 \%$ & $(268,34 \%)$ & $(7,80 \%)$ & $75,13 \%$ \\
Margin & & & & \\
\hline $\begin{array}{c}\text { Return } \\
\text { on }\end{array}$ & $7.77 \%$ & $(264,10 \%)$ & $(6,80 \%)$ & $60,72 \%$ \\
Asset & & & & \\
\hline $\begin{array}{c}\text { Return } \\
\text { on } \\
\text { equity }\end{array}$ & $16.87 \%$ & - & - & $(68,45 \%)$ \\
\end{tabular}

Net profit margin atau margin laba bersih merupakan perbandingan laba bersih dengan hasil penjualan. Dengan demikian net profit margin akan menunjukan efisiensi dalam operasi usaha. Semakin tinggi angka net profit margin, akan semakin efisien dalam pengelolaan aktivitas operasi. Tahun 2019, net profit margin menunjukan rasio yang tinggi dibandingkan tahun-tahun sebelumnya. Net profit margin negatif, menunjukan bahwa perusahaan tidak menghasilkan keuntungan dalam satu periode perhitungan. Hal ini terjadi pada tahun 2017 dan tahun 2018.

Return on Aset (ROA), menurut Hanafi dan Halim (2003) adalah rasio keuangan perusahaan yang berhubungan dengan profitabilitas ROA digunakan untuk mengevaluasi kemampuan mengelola dana. Rasio ini merupakan perbandingan antara laba dengan total aktiva. Aktiva merupakan keseluruhan modal atau kekayaan yang dimiliki perusahaan untuk digunakan membiayai operasi usaha. Semakin tinggi ROA, semakin baik perusahaan dalam pengelolaan dana. Tahun 2019, ROA menunjukkan peningkatan yang signifikan. Peningkatan ROA tahun 2019, dipengaruhi oleh beberapa faktor yang berhubungan dengan aktivitas penjualan. Pertama, Peningkatan laba yang berasal dari penghasilan lain. Penghasilan lain, artinya penghasilan yang diperoleh bukan dari usaha pokok perusahaan. Kedua, Peningkatan total aset, yaitu berasal dari aset tidak lancar. Peningkatan total aset tidak lancar dibiaya dari hutang jangka panjang. Ketiga, Peningkatan kas dan setara kas. Peningkatan tersebut didorong oleh meningkatnya penggunaan arus kas untuk aktivitas investasi.

Return on Equity, menunjukan perbandingan antara laba dengan modal perusahaan. Perhitungan terhadap rasio ini dimaksudkan untuk mengukur tingkat pengembalian modal perusahaan dari saham. Rasio ini akan merepresentasikan kekayaan bagi pemegang saham. Semakin tinggi rasio ini, berarti semakin tinggi keuntungan perusahaan, yang berarti tingkat pengembalian investasi dari pemegang saham 
akan semakin cepat. Tahun 2017 dan tahun 2018, perusahaan mengalami ekuitas negatif. Hal ini terjadi karena penurunan saldo laba hingga mencapai angka negatif. Pencatatan saldo laba negatif pada laporan keuangan akan mengikis ekuitas perusahaan. Disamping itu kondisi besarnya hutang, melebihi besarnya aset perusahaan, didalam perhitungan akan menyebabkan ekuitas negatif. Dalam kondisi keuangan tersebut, ROE tahun 2017 hingga tahun 2018 tidak dapat dijadikan indikator kinerja.

Tahun 2019, ROE dalam posisi negatif. Rasio negatif pada tahun 2019, disebabkan karena perubahan unsur laba dan modal kerja. Pertama, Peningkatan jumlah ekuitas sebesar $51,96 \%$ dibanding tahun 2018, sehingga defisit ekuitas tahun 2019 menjadi lebih kecil dari pada tahun 2018, Kedua, Peningkatan penghasilan berasal dari penghasilan lainnya/bukan dari usaha pokok perusahaan, sehingga keuntungan menjadi angka positif Ketiga, Tahun 2019 tidak melakukan perubahan saham seperti pemecahan saham, penggabungan saham, pembagian dividen, pembagian saham bonus maupun perubahan nilai nominal saham.

Tahun 2019, bagi TPSF, merupakan tahun yang akan menentukan keberlanjutan perusahaan, setelah menghadapi berbagai permasalahan keuangan yang terjadi di tahun sebelumnya. Upaya-upaya menghadapi tantangan tahun 2019, antara lain: Pertama, melakukan restrukturisasi hutang, baik hutang yang berasal dari obligasi dan sukus, maupun kewajiban kepada kreditur, sehingga hutang jangka pendek mengalami penurunan. Struktur hutang lebih besar hutang jangk panjang dibandingkan dengan hutang jangka pendek. Kedua, Total aset mengalami peningkatan, terutama pada aset tidak lancar. Ketiga, mampu memperbaiki posisi ekuitas, disebabkan karena peningkatan total aktiva dan penurunan total hutang, walau masih menunjukkan angka negatif. Keempat, mampu menciptakan diversifikasi produk, sehingga terjadi peningkatan keuntungan dari usaha lainnya, serta mampu menekan beban pokok penjualan.

\section{Kesimpulan}

Berdasarkan analisis laporan keuangan tahunan, disimpulkan bahwa PT Tiga Pilar Sejahtera Food, Tbk, pada tahun penelitian, mengalami financial distress, yaitu kondisi dimana kewajiban perusahaan terhadap pihakpihak ketiga lebih besar dari pada kekayaan yang dimiliki. Diperkuat dengan metode Altman Z-Score, pada tahun 2016, kondisi keuangan PT Tiga Pilar Sejahtera Food, Tbk, mengalami keadaan menuju kebangkrutan, selanjutnya tahun 2017 dan 2018, perusahaan berada pada kategori bangkrut. Upaya-upaya yang dilakukan perusahaan untuk mengatasi permasalahan keuangan di tahun 2016 hingga 2018, dapat meningkatkan kondisi keuangan tahun 2019, walau dengan metode Z-Score masih berada pada kategori bangkrut, namun terjadi peningkatan score.

Metode Altman Z-score, dapat digunakan untuk mengindikasikan keadaan kesehatan keuangan perusahaan, dengan lebih menitikberatkan pada pengelolaam total kekayaan atau total aktiva. Tahun 2019 terjadi upaya penyelamatan kondisi keuangan, sehingga perusahaan dapat meningkatkan rasio keuangan. Kemampuan pengelolaan kekayaan telah dapat memberikan jaminan operasional perusahaan, kemampuan membayar kewajiban keuangan, dan kemampuan menghasilkan penjualan.

Didukung dengan perhitungan rasio profitabilitas, kondisi keuangan tahun 2019 menunjukkan peningkatan rasio. Akan tetapi peningkatan rasio, lebih disebabkan adanya peningkatan keuntungan dari usaha lainnya, bukan usaha pokok perusahaan.

\section{Saran}

Berdasarkan kesimpulan dari hasil penelitian ini, perlu disarankan untuk penelitian-penelitian selanjutnya, antara lain: (1) Analisis terhadap kondisi keuangan perusahaan, tidak cukup hanya menggunakan 1 metode yaitu Altman Z-Score. Perlu dihitung dengan menggunakan metode lainnya, antara lain: Zmijewski X-Score; (2) 
periode waktu penelitian lebih diperbanyak, misalnya 5 tahun.

Metode penetapan kategori kesehatan keuangan perusahaan, hendaknya dapat digunakan untuk menjadi pedoman penetapan kebijakan keuangan dimasa yang akan datang, sehingga keuntungan dari usaha pokok dapat ditingkatkan, serta menghindari penelitian pada emiten yang memiliki opini audit disclaimer.

\section{Reference}

Almilia, Luciana., \& Kristijadi. (2003). Analisis Rasio Keuangan untuk Memprediksi Kondisi Financial Distress Perusahaan Manufaktur yang Terdaftar di Bursa Efek Jakarta. Jurnal Akuntansi dan Auditing Indonesia (JAAI), Volume 7 Nomor 2. hal 25.

Altman, E. I,. (1968). Financial Ratios, Discriminant Analysis And The Prediction of Corporate Bankruptcy. The Journal of Finance, Vol. 23,pp 589-609.

Arum, Dian Puspita., \& Handayani, Siti Ragil. (2018). Analisis Perbandingan Metode Altman (Z-Score), Springate (S-Score), Dan Zmijewski (X-Score) Dalam Memprediksi Kebangkrutan Perusahaan (Studi Pada Perusahaan Tekstil Dan Garmen Yang Terdaftar Di Bursa Efek Indonesia Periode 2012-2016). Jurnal Administrasi Bisnis, Vol 60, No 1, hal 45.

Brigham, E.F., \& Daves, P.R. (2003). Intermediate Financial Management with Thomson One. United States of America: Cengage SouthWestern.

Brigham, Eugene F., \& Houston, Joel F. (2011). Dasar-dasar Manajemen Keuangan. Jakarta: Salemba empat.

Dahni, Fanita. (2019). Altman Z-Score Vs Zmijewski X-Score Dalam Memprediksi Kebangkrutan Perusahaan (Studi Kasus PT Tiga Pilar Sejahtera Food, Tbk (AISA) Tahun 2015-2017. Jurnal Administrasi Bisnis Volume 8, No 2.
Damodaran, A. (1997). Corporate Finance Theory and practice. New York: John Willey \& Sons, Inc.

Fakhrurozie. (2007). Analisis Pengaruh Kebangkrutan Bank dengan Metode Altman Z-Score terhadap Harga Saham. Skripsi. Semarang: Universitas Negeri Semarang.

Gitman, Lawrence, J. (2006). Principles of Managerial Finance, Eleventh Edition United States of America: Wesley Publishing Company, Inc.

Hanafi, Mamduh., \& Halim, Abdul. (2003). Analisis Laporan Keuangan. Edisi Revisi. Yogyakarta: UPP AMP YKPN.

Hanafi, Mamduh. (2016). Analisis Laporan Keuangan. Yogyakarta:UPP STIM YKPM

Van Horne, James C. \& Jhon M. Wachowicz. (2005). Prinsip-prinsip Manajemen Keuangan, Edisi 12, Jakarta: Salemba Empat

Kamaludin, Karona, dan Berto. (2015). Restrukturisasi Merger \& Akuisisi, Bandung: Mandar Maju.

Kasmir. (2016). Analisis Laporan Keuangan. Jakarta: Raja Grafindo Persada.

Rahayu, Putri. (2016). Analisis Penggunaan Metode Springate (S-Score) Sebagai Prediktor Kebangkrutan (Studi Pada Perusahaan Textile Yang Terdaftar Di Bursa Efek Indonesia Pada Tahun 20112013). Jurnal Akuntansi, Vol 4.

Sundjaja, Ridwan S. dan Inge Barliaan (2004) Manajemen Keuangan 2, Jakarta: Literata Lintas Media.

Rudianto. (2013). Akuntansi Manajemen Informasi untuk Pengambilan Keputusan Strategis. Jakarta: Erlangga

Sawir, Agnes (2005). Analisis Kinerja Keuangan dan Perencanaan Keuangan. Jakarta: PT.Gramedia Pustaka Utama

Prihadi, Toto. (2013). Analisis Laporan Keuangan Teori dan Aplikasi. Jakarta: PPM 
Laporan tahunan perusahaan PT TPS Food tahun 2016 hingga tahun 2019, yang dipublikasikan melalui https://tpsfood.id/relasi-

investor/laporan-tahunan/, diunduh 3 desember 2019 